\title{
Sexual Violence and Associated Factors Against Housemaid's Living in Debre-Tabor Town, Northwest Ethiopia.
}

Kefyalew Amogne Azanaw ( $\sim$ kefyalewamogne@gmail.com )

debretabor health science college https://orcid.org/0000-0002-9760-4841

Abebaw Addis Gelagay

university of gondar

Ayenew Molla Lakew

university of gondar

\section{Research}

Keywords: housemaid, sexual violence, prevalence, Debre Tabor, Ethiopia

Posted Date: July 1st, 2020

DOl: https://doi.org/10.21203/rs.3.rs-36729/v1

License: (1) (i) This work is licensed under a Creative Commons Attribution 4.0 International License.

Read Full License 


\section{Abstract}

Objectives: Sexual violence is a serious public health and human rights problem with both short and long term consequence on women's physical, mental, sexual and reproductive health. But no sufficient study about housemaid sexual violence conducted in Ethiopia. Therefore, the aim of this study is to assess the magnitude of sexual violence and its associated factors among housemaids living in Debre Tabor town, North West Ethiopia 2018.

Results: From 636 participants included in the study $27.8 \%$ (95\% Cl: $24.2 \%-31.4 \%$ ) housemaids had experienced sexual violence in their life time. Housemaid who had no formal education( $A O R=2.1,95 \% \mathrm{Cl}=1.13,3.76)$, housemaid coming from rural $(A O R=2.73,95 \% \mathrm{Cl}=1.31,5.69)$, housemaids whose both parents dead $(A O R=2.6,95 \% \mathrm{Cl}=1.47,4.61)$, employer who had extended family in the house $(\mathrm{AOR}=2.9,95 \% \mathrm{Cl}=1.77,4.75)$, male employer alcohol consumption( $\mathrm{AOR}=2.56,95 \% \mathrm{Cl}=1.61$, 4.1) and age of female employer $\geq 50$ years $(A O R=4.29,95 \% \mathrm{Cl}=1.95,9.48)$ were increase the probability of housemaids' sexual violence. In conclusion this study, high prevalence of housemaid violence has been reported. To resolve the problem, it is important to create awareness and bring behavioral change to empower housemaid.

\section{Plain English Summary}

Sexual violence is a serious public health and human right problems with sort and long term health consequences. Impression of sexual violence accounts disability, depression, physical and reproductive problems and risky sexual behavior.

However, there are many study conducted on sexual violence in the world and also in Ethiopia, there is lake of documents about violence against housemaids.

A community based cross-sectional study design was conducted for 636 study participants with a structured, pre-tested interviewer administered questionaries' adopted from world health organization multi country study.

From 636 study participants, $177(27.8 \%)$ and $69(10.8 \%)$ have been experienced sexual violence in their life time and the past 12 months respectively. Participants who had no formal education, resided from countryside, whose parents dead, employers who had extended family living in the house, male employers alcohol consumption, and female employers age $>=50$ years were important predictors of housemaid sexual violence.

In conclusion, local government officials like, labor and social affair office and women and children affair office need to provide special support and protection to housemaids. Further research need to address the economical violence of housemaid is very important.

\section{Introduction}


Sexual violence can be defined as "any sexual act, attempt to obtain a sexual act, or other act directed against a person's sexuality using coercion, by any person regardless of their relationship to the victim, in any setting, including but not limited to home and work". Sexual violence can include the following threat of rape attempted rape, rape, Sexual harassment and sexual contact with force[1].

Violence against women is a public health problem as well as a basic violation of women's human rights[2]. The impact of violence is beyond physical injuries it also accounts disability, depression, physical and reproductive problem, and risky sexual behavior[3].

In the world 10 up to $50 \%$ of women suffered with sexual violence by their intimate partners[4]. in subSaharan Africa the experience of women with physical and/or sexual violence by their intimate partner ranges from $27-59 \%[5]$. In Ethiopia 59\% of women were exposed to sexual violence[4].

Generally, in the countries where the statuses of women are low, younger women are more likely to suffer from domestic violence. Ethiopia has one of the highest prevalence of both physical and sexual violence by their intimate partner[6]. Most study conducted on violence against women agreed that lower educational status, abuse of (alcohol, kchat, and smoke) and younger women are more likely increase experience of violence against women [7-9].

Gender based violence affected the significant segment of populations on girls and women across all group and classes[10]. At worldwide with in its informal nature of domestic worker still challenge to regulation and policy implementation lead to limited opportunities of access to social and legal protection[11].

Universally, all type of violence overlap in relationship and a significant public health problem worldwide but the level and pattern of violence greatly varies between setting, culture and segment of the population[12].

Even though there are many studies conducted on violence in the globe and also in our country Ethiopia in all segment of girls and/or women, there is lack of information about magnitude and associated factors of sexual violence against housemaids.

Therefore, this study amide to assess the magnitude of sexual violence and also tried to identify factors associated with sexual violence among housemaid. So, this research finding hope to alleviate scarce of information on housemaids sexual violence in Debre-Tabor town northwest Ethiopia.

\section{Methods}

\section{Study design and period}

Community based cross- sectional study was conducted in Debre-Tabor town northwest Ethiopia from April, 1-30/ 2018. Debre Tabor is the capital town of South Gondar zone which is located $666 \mathrm{~km}$ far 
from Addis Ababa the capital city of Ethiopia; to northwest Ethiopia. As the data obtained from South Gondar zone city administration the town had 92,530 populations (2010 EPY).

\section{Sample size and sampling procedure}

A sample of 541 study participants was determined using single population proportion formula taking $28.6 \%$ prevalence of sexual violence against housemaids[13], considering $95 \% \mathrm{Cl}, 5 \%$ margin of error, 1.5 design effect and $15 \%$ non-respondent rate. Finally 636 participants were included in the study. Cluster sampling was used to select study participants. In the study area there are four Kebeles; from those kebeles $50 \%$ of ketenas was selected by using simple random sampling, and the sample size was proportionally allocated for each kebele and study participants in the households were selected from all selected Ketenas until achieving the required number of respondents.

\section{Data collection procedures}

A structured, pre-tested Interviewer administered questionnaire adopted from WHO multi country study was used. The questionnaire was translated in to the local language Amharic and pretested was administered on $5 \%$ of the sample at Woreta town. Four MPH for supervisors and 8 health extension workers for data collectors were recruited and training was provided for 3 days. Sexual violence was taken as the dependent variable while employers' characteristics and housemaids' characteristics were considered as independent variables. Housemaid violence was measured as if a housemaid experience any acts physically forced to have sexual intercourse when she did not want to and/or because she was afraid of what partner might do and/or had unwanted sex position and/or had unwanted warm up for sex was considered as "yes" otherwise "no"[4].

\section{Data quality control}

Data were collected by well-trained data collectors using pretested questionnaires. Training was given to supervisors and data collectors. Data were reviewed and checked for its completeness before entering for analysis.

\section{Data processing and analysis:}

Data were entered into Epi- info version 7.2.2.6 and exported into SPSS version 20.0. The data were also cleaned, coded, and analyzed with SPSS. Descriptive analysis was done to describe the different characteristics of the employers and housemaids. Binary logistic regression analysis was done to identify association between independent and dependent variables. To identify factors significantly associated with the outcome variable adjusted odds ratio (AOR) with 95\% confidence interval (Cl) was used. Variable having $p$-value less than 0.05 were considered as significant predictors.

\section{Results}

\section{Socio-demographic characteristics of housemaids}


About 636 of were participated in the study, among the participants $386(60.7 \%)$ were in the age group of $15-19$ years, with the mean age of $19.76( \pm 4.63 \mathrm{SD})$ years. About $319(50.2 \%)$ of participants had no formal education. Majority 525(82.5\%) of were previously resided in rural area. About $593(93.2 \%)$ of were orthodox Christian. Around 570(89.6\%) of housemaid were single. About $255(40.1 \%)$ of them had both father and mother. Participants, 302(47.5\%) were paid from 301-500 ETB. Concerning work experience $448(70.4 \%)$ of housemaid had $1-4$ years of work experience. About $414(65.1 \%)$ were start work at the age of 15 years and above. (Table1) 
Table 1

Socio-demographic characteristics of housemaid, Debre Tabor town, 2018

\begin{tabular}{|c|c|c|c|}
\hline Characteristics & & Number & Percent \\
\hline \multirow[t]{3}{*}{ Age of female employer } & $\leq 29$ & 103 & 17.9 \\
\hline & $30-49$ & 405 & 70.6 \\
\hline & $\geq 50$ & 66 & 11.5 \\
\hline \multirow[t]{3}{*}{ Age of male employer $(n=636)$} & $\leq 29$ & 14 & 2.2 \\
\hline & $30-49$ & 433 & 67.9 \\
\hline & $\geq 50$ & 190 & 29.9 \\
\hline \multirow[t]{3}{*}{ Female employer religion $(n=626)$} & Orthodox & 495 & 86.2 \\
\hline & Protestant & 20 & 3.5 \\
\hline & Muslim & 59 & 10.3 \\
\hline \multirow[t]{3}{*}{ Male employer religion $(n=636)$} & Orthodox & 552 & 86.8 \\
\hline & Protestant & 23 & 3.6 \\
\hline & Muslim & 61 & 9.6 \\
\hline \multirow{5}{*}{$\begin{array}{l}\text { Female employer educational status }(\mathrm{n}= \\
626)\end{array}$} & Not read and write & 48 & 8.4 \\
\hline & $\begin{array}{l}\text { Read } \& \text { write but no formal } \\
\text { education }\end{array}$ & 48 & 8.4 \\
\hline & Grade $1-8$ & 56 & 9.8 \\
\hline & Grade $9-12$ & 127 & 22.1 \\
\hline & Certificate and above & 295 & 51.4 \\
\hline \multirow{5}{*}{$\begin{array}{l}\text { Male employer educational status }(n= \\
636 \text { ) }\end{array}$} & Not read and write & 4 & 0.6 \\
\hline & $\begin{array}{l}\text { Read } \& \text { write but no formal } \\
\text { education }\end{array}$ & 40 & 6.3 \\
\hline & Grade $1-8$ & 42 & 6.6 \\
\hline & Grade $9-12$ & 83 & 13.1 \\
\hline & Certificate and above & 467 & 73.4 \\
\hline \multirow[t]{3}{*}{ Marital status of employers } & Married & 536 & 84.3 \\
\hline & Single & 35 & 5.5 \\
\hline & Divorced & 40 & 6.3 \\
\hline
\end{tabular}




\begin{tabular}{|c|c|c|c|}
\hline \multicolumn{2}{|l|}{ Characteristics } & \multirow{2}{*}{$\begin{array}{l}\text { Number } \\
25\end{array}$} & \multirow{2}{*}{$\begin{array}{l}\text { Percent } \\
3.9\end{array}$} \\
\hline & Widowed & & \\
\hline \multirow[t]{3}{*}{ Number of children employer have } & $0-3$ & 451 & 70.9 \\
\hline & $4-6$ & 178 & 28 \\
\hline & $\geq 7$ & 7 & 1.1 \\
\hline \multirow[t]{3}{*}{ Employer family size } & $1-3$ & 167 & 26.3 \\
\hline & $4=6$ & 412 & 64.8 \\
\hline & $\geq 7$ & 57 & 9 \\
\hline \multirow[t]{2}{*}{ Extended family living with employer } & Yes & 132 & 20.8 \\
\hline & No & 504 & 79.2 \\
\hline \multirow[t]{2}{*}{ Another housemaid living with employers } & Yes & 28 & 4.4 \\
\hline & No & 608 & 95.6 \\
\hline \multirow[t]{6}{*}{ Female employer occupational } & Housewife & 142 & 24 \\
\hline & Student & 7 & 1.1 \\
\hline & Government employer & 269 & 47 \\
\hline & Private employer & 59 & 10.5 \\
\hline & Merchant & 89 & 15.7 \\
\hline & Pensioned & 8 & 1.8 \\
\hline \multirow[t]{4}{*}{ Male employer occupation } & Government employer & 387 & 60.7 \\
\hline & Private employer & 98 & 15.4 \\
\hline & Merchant & 122 & 19.2 \\
\hline & Pensioned & 29 & 4.6 \\
\hline
\end{tabular}

The mean ages of female and male employers were 33.64 and 43.37 years respectively Majority, 495(86.2\%), of female employer and 552(86.8\%) of male employer were orthodox Christians. About $295(51.4 \%)$ of female employers and $467(73.4 \%)$ of male employers had certificate and above. Majority, $536(84.3 \%)$, of employers were married. About $451(70.9 \%)$ of employers had 0-3number of children and $412(64.8 \%)$ of employers had 4-6 family size. about 504 (79.2\%) of employers had no extended family and only $28(4.4 \%)$ of employers had another housemaid. About 269(46.9\%) of female employers and 
$387(60.7 \%)$ of male employers were government employee. about $30(4.7 \%)$ of employer had smoking cigarette and $70(11 \%)$ of employers had chewing khat. Ninety $(15.7 \%)$ of female employers and $158(24.8 \%)$ of male employers had consumed alcohol.(Table 2$)$ 
Table 2

Socio-demographic characteristics of employers, Debre Tabor town, 2018

\begin{tabular}{|c|c|c|}
\hline Characteristics & Number & Percent (\%) \\
\hline \multicolumn{3}{|l|}{ Age of female employer } \\
\hline$\leq 29$ & 103 & 17.9 \\
\hline $30-49$ & 405 & 70.6 \\
\hline$\geq 50$ & 66 & 11.5 \\
\hline \multicolumn{3}{|l|}{ Age of male employer $(n=636)$} \\
\hline$\leq 29$ & 14 & 2.2 \\
\hline $30-49$ & 433 & 67.9 \\
\hline$\geq 50$ & 190 & 29.9 \\
\hline \multicolumn{3}{|l|}{ Female employer religion $(n=626)$} \\
\hline Orthodox & 495 & 86.2 \\
\hline Protestant & 20 & 3.5 \\
\hline Muslim & 59 & 10.3 \\
\hline \multicolumn{3}{|l|}{ Male employer religion $(n=636)$} \\
\hline Orthodox & 552 & 86.8 \\
\hline Protestant & 23 & 3.6 \\
\hline Muslim & 61 & 9.6 \\
\hline \multicolumn{3}{|l|}{ Female employer educational status $(n=626)$} \\
\hline Not read and write & 48 & 8.4 \\
\hline Read and write but no formal education & 48 & 8.4 \\
\hline Grade 1-8 & 56 & 9.8 \\
\hline Grade $9-12$ & 127 & 22.1 \\
\hline Certificate and above & 295 & 51.4 \\
\hline \multicolumn{3}{|l|}{ Male employer educational status $(n=636)$} \\
\hline Not read and write & 4 & 0.6 \\
\hline Read and write but no formal education & 40 & 6.3 \\
\hline Grade 1-8 & 42 & 6.6 \\
\hline Grade $9-12$ & 83 & 13.1 \\
\hline
\end{tabular}




\begin{tabular}{|c|c|c|}
\hline Characteristics & Number & Percent (\%) \\
\hline Certificate and above & 467 & 73.4 \\
\hline \multicolumn{3}{|c|}{ Marital status of employers } \\
\hline Married & 536 & 84.3 \\
\hline Single & 35 & 5.5 \\
\hline Divorced & 40 & 6.3 \\
\hline Widowed & 25 & 3.9 \\
\hline \multicolumn{3}{|c|}{ Number of children employer have } \\
\hline $0-3$ & 451 & 70.9 \\
\hline $4-6$ & 178 & 28 \\
\hline$\geq 7$ & 7 & 1.1 \\
\hline \multicolumn{3}{|l|}{ Employer family size } \\
\hline $1-3$ & 167 & 26.3 \\
\hline $4=6$ & 412 & 64.8 \\
\hline$\geq 7$ & 57 & 9 \\
\hline \multicolumn{3}{|c|}{ Extended family living with employer } \\
\hline Yes & 132 & 20.8 \\
\hline No & 504 & 79.2 \\
\hline \multicolumn{3}{|c|}{ Another housemaid living with employers } \\
\hline Yes & 28 & 4.4 \\
\hline No & 608 & 95.6 \\
\hline \multicolumn{3}{|c|}{ Female employer occupational } \\
\hline Housewife & 142 & 24 \\
\hline Student & 7 & 1.1 \\
\hline Government employer & 269 & 47 \\
\hline Private employer & 59 & 10.5 \\
\hline Merchant & 89 & 15.7 \\
\hline Pensioned & 8 & 1.8 \\
\hline
\end{tabular}




\begin{tabular}{|lll|}
\hline Characteristics & Number & Percent (\%) \\
\hline Government employer & 387 & 60.7 \\
\hline Private employer & 98 & 15.4 \\
Merchant & 122 & 19.2 \\
\hline Pensioned & 29 & 4.6 \\
\hline
\end{tabular}

\section{Prevalence of housemaid sexual violence}

From all study participants, $177(27.8 \%)(95 \% \mathrm{Cl}: 24.2 \%-31.4 \%)$ have been experienced at least one type of sexual violence in their life time and 69 (10.8\%) (95\% Cl: 8\%-13.2\%) experienced in the past 12 months.

\section{Factors associated with housemaid sexual violence}

In bi-variable logistic regression analysis educational status, previous resident, family live situation, employer alcohol consumption, marital status of housemaid, marital status of employers, age of female employer and extended family living with employers were significantly associated with housemaid sexual violence. In the final model, educational status, previous resident, family live situation, age of female employer, extended family living with employers and male employer alcohol consumption were remaining significantly associated with lifetime housemaid sexual violence at $5 \%$ level of significance.

The result of the study revealed that housemaids who had no formal education were 2 times (AOR $=2.06$ $95 \% \mathrm{Cl}: 1.13,3.76)$ more likely to experienced sexual violence as compared to those who had secondary education and above.

Pertaining to resident of housemaids, housemaids who previously lived at rural areas were 3 times (AOR $=2.73,95 \% \mathrm{Cl}: 1.31,5.69)$ more likely to experience sexual violence than those who resided at urban.

Housemaid whose both parents dead were 3 times ( $\mathrm{AOR}=2.6,95 \% \mathrm{Cl}: 1.47,4.61)$, more likely to experienced sexual violence as compared to those who had both father and mother alive.

Housemaids whose employer have extended family living with them were 3 times (AOR $=2.9,95 \% \mathrm{Cl}: 1.77$, 4.75) more likely experienced sexual violence.

Participants whose their female employer age $\geq 50$ years old were 4 times $(A O R=4.29,95 \% \mathrm{Cl}: 1.95,9.48)$ more likely experienced than those $\leq 29$ years old.

With regard to alcohol consumption, housemaid whose male employer drank alcohol were 3 times (AOR $=2.56,95 \% \mathrm{Cl}: 1.61,4.1)$ more likely to experience sexual violence as compared to those who not drank alcohol (Table 3). 
Table 3

Factors associated with lifetime experience of housemaid sexual violence, Debre Tabor town, 2018

\begin{tabular}{|c|c|c|c|c|c|}
\hline \multirow[t]{2}{*}{ Variables } & & \multicolumn{2}{|c|}{$\begin{array}{l}\text { Housemaid } \\
\text { sexual violence }\end{array}$} & \multirow[t]{2}{*}{$\operatorname{coR}(95 \% \mathrm{Cl})$} & \multirow[t]{2}{*}{ AOR(95\%Cl) } \\
\hline & & Yes & No & & \\
\hline \multirow[t]{3}{*}{ Educational status } & $\begin{array}{l}\text { No formal } \\
\text { education }\end{array}$ & 109) & 210 & $1.9(1.20,3.03)$ & $2.06\left(1.13,3.76^{*}\right.$ \\
\hline & $\begin{array}{l}\text { Primary } \\
\text { education }\end{array}$ & 38 & 139 & $0.99(0.85,1.72$ & $1.20(0.61,2.36)$ \\
\hline & $\begin{array}{l}\text { Secondary } \\
\text { education and } \\
\text { above }\end{array}$ & 30 & 110 & 1 & 1 \\
\hline \multirow[t]{2}{*}{ Previous residence } & Urban & 15 & 96 & 1 & 1 \\
\hline & Rural & 162 & 363 & $2.86(1.61,5.08)$ & $2.73(1.31,5.69) *$ \\
\hline \multirow{4}{*}{$\begin{array}{l}\text { Marital status of } \\
\text { housemaid }\end{array}$} & Married & 18 & 15 & 1 & 1 \\
\hline & Single & 143 & 427 & $0.28(0.14,0.57)$ & $0.48(0.20,1.17)$ \\
\hline & Divorce & 7 & 11 & $0.53(0.17,1.71)$ & $0.27(0.05,1.37)$ \\
\hline & Windowed & 9 & 6 & $1.25(0.36,4.32)$ & $0.72(0.16,3.15)$ \\
\hline \multirow[t]{4}{*}{ Family live situation } & $\begin{array}{l}\text { Both father and } \\
\text { mother alive }\end{array}$ & 44 & 211 & 1 & 1 \\
\hline & Only father alive & 32 & 73 & $2.1(1.24,3.56)$ & $1.73(0.89,3.34)$ \\
\hline & $\begin{array}{l}\text { Only mother } \\
\text { alive }\end{array}$ & 38) & 93 & $1.96(1.19,3.22)$ & $2.00(1.40,3.69)$ \\
\hline & $\begin{array}{l}\text { Both father and } \\
\text { mother not alive }\end{array}$ & 63 & 82 & $3.68(2.32,5.85)$ & $2.6(1.47,4.61) \star *$ \\
\hline \multirow{2}{*}{$\begin{array}{l}\text { Extended } \\
\text { family/relative living } \\
\text { with employer }\end{array}$} & Yes & 60 & 72 & $2.76(1.85,4.11)$ & $2.9(1.77,4.75) * *$ \\
\hline & No & 117) & 387 & 1 & 1 \\
\hline \multirow{3}{*}{$\begin{array}{l}\text { Age of female } \\
\text { employers }\end{array}$} & $\leq 29$ & 18 & 85 & 1 & 1 \\
\hline & $30-49$ & 94 & 311 & $1.43(0.82,2.49)$ & $1.33(0.73,2.41)$ \\
\hline & $\geq 50$ & 31 & 35 & $4.18(2.07,8.44)$ & $4.29(1.95,9.48) \star \star$ \\
\hline \multirow{4}{*}{$\begin{array}{l}\text { Employer marital } \\
\text { status }\end{array}$} & Married & 133 & 403 & 1 & 1 \\
\hline & Single & 17 & 18 & $2.86(1.43,5.71)$ & $1.14(0.30,4.33)$ \\
\hline & Divorce & 19 & 21 & $2.74(1.43,5.26)$ & $0.43(0.11,1.74)$ \\
\hline & Windowed & 8 & 179 & $1.42(0.60,3.38)$ & $0.83(0.26,2.69)$ \\
\hline
\end{tabular}




\begin{tabular}{|lccccc|}
$\begin{array}{l}\text { Male employers } \\
\text { alcohol consumption } \\
\text { status }\end{array}$ & Yes & 75 & 83 & $3.33(2.28,4.88)$ & 2.56(1.61,4.07)** \\
\cline { 2 - 5 } & No & 102 & 376 & 1 & 1 \\
\cline { 2 - 6 }
\end{tabular}

\section{Keys: 1 = reference $*=$ significant with $p<0.005$, **=significant with $p<0.001$}

\section{Discussion}

This study tried to find the prevalence and factors associated with housemaid sexual violence in Debre Tabor town. The prevalence of sexual violence during their life time was $(27.8 \%)(95 \% \mathrm{Cl}=24.2,31.4)$ which is in line with the finding from Addis Ababa, Ethiopia(28.6\%), Bair Dar, northwest Ethiopia(24.3\%) and Nekemte town, western Ethiopia(26.1\%)[13-15]. The finding was higher as compared to a study conducted in eastern Sudan(17\%)[16]. This discrepancy could partly be due to socio-demographic difference, the other study conducted on government employees. Women who had better employment status could have access of information about violence and they can easily protect themselves.

Housemaids who have no formal education were 2 times more likely to experience sexual violence. Comparable finding was obtained from a study conducted in shimelba refugee camp, northern Ethiopia, Eastern Sudan, and Eastern India showed that women less than secondary education were more likely experience violence $[8,16,17]$. This is due to the fact that low educational status of women had no power to protect the violence.

Housemaid who resided in rural areas was 3 times more likely to experienced sexual violence as compared to who resided urban area. This finding was consistent with a study conducted in Eastern India, Gondar town northwest Ethiopia and around Gondar northwest Ethiopia showed that rural residency were more likely experience violence where compared to urban residence[17-19]. Housemaids who came from rural had no information about violence and they couldn't complain to legal bodies. But this finding contradicted with a study from Ghana, showed that women who resided urban areas were $35 \%$ more likely increase risk of domestic violence[20] this could be due to socio-demographic and sociocultural difference of the study participants.

Housemaid who had no both parents were 3 times more likely experience lifetime sexual violence when compared to those who had both father and mother alive respondents. Family support could increase the confidence of housemaid this help to protect them from any violence.

Participants whose employer had extended family living with them were 3 times more likely experienced with sexual violence. Extended family could be increase the exposure of sexual violence due to crowded family size and poor follow-up.

Housemaids whose female employer aged $\geq 50$ years old were 4 times more likely exposed to sexual violence when compared to female employer aged $\leq 29$ years old. This is due to the fact that increase 
age of the wife could be decrease sexual interest of the husband with hers and shifting sexual relation to housemaid.

Participants whose male employer drank alcohol were 3 times more likely experience life time housemaid sexual violence when compared to participants whose employer not take alcohol. This finding consistent with a study conducted in Mekele town, northern Ethiopia, Addis Ababa and Debre Tabor town northwest Ethiopia showed that housemaid whose employer drink alcohol were more likely experience violence than those whose employer not drink alcohol $[9,13,21]$. This is due to the fact that alcohol has depressive mental impairment and which encourages human beings to undertake violence against their house maids.

\section{Conclusion}

In this study, high prevalence of housemaid sexual violence has been reported. Being rural resident, no formal education, both parent dead, extended family living with employers, age of female employer and alcohol consumption of male employers were important predictors of housemaid sexual violence. Local government officials like, labor and social affair office and women and children office need to expand of information education communication and behavioral change on housemaid to empower and report violence as a crime and also need to improve community awareness about housemaid violence.

\section{Limitation Of The Study}

The limitation of this study was the data collectors interviewed only housemaid as a proxy respondents for their employer that depend on housemaid report only, this lead to bias when they come to reporting employer characteristics. And have been encountered with social desirability bias due to sensitivity of the information and also exposed with recall bias due to the nature of cross-sectional design.

\section{Abbreviations}

AOR

Adjusted Odds Ratio, Cl:Confidence Interval, COR:Crude Odds Ratio,

ETB

Ethiopian Birr, OR:Odds Ratio, SD:Standard Deviation, SPSS:Statistical Package for Social Sciences, WHO:World Health Organization.

\section{Declarations}

\section{Ethical approval and consent to participate:}

Ethical approval was obtained from university of Gondar, institute of public health ethical review committee. Official letter was obtained from Debre Tabor town administration, mayor office. From each participant, whose age 18 years and above written informed consent was obtained. Participants who 
less than 18 years age written assent was obtained from their employers after clearly describing the purpose, benefit, and risk of the study and their right on decision of participation in the study. Their name was omitted for assurance of confidentiality and privacy. Interview was performed at suitable and secure place to respondents. Finally questionnaire was cleaned, stored and analyzed at secured place.

\section{Consent to publish}

Not applicable

\section{Availability of Data and Materials}

The datasets analyzed during this study are available from the authors on reasonable request.

\section{Competing interest}

The authors declare that they have no competing interest.

\section{Funding}

There was no external funding source for this study.

\section{Authors' contributions}

KAA designed the study, developed the proposal, participated in the data collection, performed analysis and interpretation of data and drafted the paper. AAG and AML assisted in the design of the study, proposal writing, data analysis, and interpretation of the study. KAA carried out the manuscript preparation. All authors reviewed and approved the final manuscript.

\section{Acknowledgements}

We are highly grateful to thank the study participants, data collectors and supervisors.

\section{References}

1. Khan M, Kapoor S, Cooraswamy R. Domestic violence against women and girls. Innocenti Digest. 2000;6:1-30.

2. Organization WH. Global and regional estimates of violence against women: prevalence and health effects of intimate partner violence and non-partner sexual violence: World Health Organization; 2013.

3. Jacob K. Global status report on violence prevention 2014. 2016.

4. Organization WH. WHO multi-country study on women's health and domestic violence against women: summary report of initial results on prevalence, health outcomes and women's responses. 2005. 
5. Borwankar R, Diallo R, Sommerfelt AE. Gender-based violence in sub-Saharan Africa: a review of Demographic and Health Survey findings and their use in national planning. 2008.

6. Berhane Y. Ending Domestic violence against women in Ethiopia. The Ethiopian Journal of Health Development (EJHD). 2017;18(3).

7. Abeya SG, Afework MF, Yalew AW. Intimate partner violence against women in western Ethiopia: prevalence, patterns, and associated factors. BMC Public Health. 2011;11(1):913.

8. Girmatsion F, Mulusew G. Intimate partner physical violence among women in Shimelba refugee camp, northern Ethiopia. BMC Public Health. 2012;12(1):125.

9. Milete Zenebe AG. Huruy Assefa. Magnitude and factors associated to physical violence among house maids of Mekelle town, Tigray, northern, Ethiopia: A cross sectional study. science publishing group. 2014(2328-5745).

10. Group IGW. Addressing gender-based violence through USAID'S health programs: a guide for health sector program officers. Addressing gender-based violence through USAID'S health programs: a guide for health sector program officers: IGWG; 2006.

11. Blackett A. Exploited, Undervalued-and Essential: Domestic Workers and the Realisation of their Rights. Edited by Darcy du Toit. Pretoria: Pretoria University Law Press, 2013. 380 pp. ZAR225. 00, \$22 paperback, available online. Wiley Online Library; 2015.

12. Heise L, Fulu E. What works to prevent violence against women and girls? State of the field of violence against women and girls: what do we know and what are the knowledge gaps. Pretoria: Medical Research Council; 2014.

13. Bsc MG. Prevalence and determinants of sexual violence among female housemaids in selected junior secondary night school: cross sectional study Addis Ababa, Ethiopia 2015: ADDIS ABABA UNIVERSITY; 2015.

14. Misganaw AC, Worku YA. Assessment of sexual violence among street females in Bahir-Dar town, North West Ethiopia: a mixed method study. BMC Public Health. 2013;13(1):825.

15. Garoma S, Belachew T, Wondafrash M, Duke N, Sieving R, Pettingell S. Sexual coercion and reproductive health outcomes among young females of Nekemte Town, South West Ethiopia. Ethiop Med J. 2008;46(1):19-28.

16. Ali AA, Yassin K, Omer R. Domestic violence against women in Eastern Sudan. BMC Public Health. 2014;14(1):1136.

17. Babu BV, Kar SK. Domestic violence against women in eastern India: a population-based study on prevalence and related issues. BMC Public Health. 2009;9(1):129.

18. Bifftu BB, Dachew BA, Tadesse Tiruneh B, Zewoldie AZ. Domestic Violence among Pregnant Mothers in Northwest Ethiopia: Prevalence and Associated Factors. Advances in Public Health. 2017;2017.

19. Yigzaw T, Yibric A, Kebede Y. Domestic violence around Gondar in northwest Ethiopia. Ethiopian Journal of Health Development. 2004;18(3):133-9. 
20. Adjah ESO, Agbemafle I. Determinants of domestic violence against women in Ghana. BMC Public Health. 2016;16(1):368.

21. AA Muche AAaAA. Magnitude and correlates of gender-based violence among married women in Northwest Ethiopia. Afr J Med Med Sci. 2017;46:213-25.

\section{Supplementary Files}

This is a list of supplementary files associated with this preprint. Click to download.

- Coverletter.docx 